\title{
The Development of Information Technology Applications of Religious Charity Through Humanities Technology Approach
}

\author{
${ }^{1}$ AGUS SYIHABUDIN, ${ }^{2}$ ASEP WAWAN JATNIKA, \\ ${ }^{3}$ ALAMTA SINGARIMBUN, ${ }^{4}$ SHOHIB KHOIRI
}

\author{
1,2,3,4) Sosioteknologi, Institut Teknologi Bandung, Jl. Ganesha 10 Bandung, Indonesia \\ 19.syihab01@gmail.com, 2aswan_jatnika@yahoo.com, ${ }^{3}$ alamta@fi.itb.ac.id, ${ }^{4}$ shohibkhoiri2016@gmail.com
}

\begin{abstract}
There are currently various non-governmental organizations, related to both religious missions and social missions, that motivate the growth of the spirit of generosity. At the same time, these organizations facilitate the collection of donations from donors and subsequently distribute these alms to people who are deemed entitled to them. The charitable institutions have developed significantly, both in terms of fundraising and distribution, partly due to the effective use of online approaches. In its development, the role of online technology has proven to have two opposite effects. In addition to the ease of access to information and effectiveness in facilitating generosity, online approaches are proven to have eliminated the emotional connections between the subjects and the objects of the charitable deeds, in this case between the donors and the recipients. Philanthropic attitudes related to religion, for example, are intended to foster humanistic relationships between the givers and the receptors. This study examines the management of online fundraising, the weaknesses and factors that hamper its implementation, and the quests for the solutions to this problem. This research is a descriptive qualitative study using direct observations over online media as the method for data collection techniques and technoculture for the analysis, supported by literature studies. The main result of this research is the holistic concept of perfecting the fundraising system and online services hence more humane.
\end{abstract}

Keywords: charity, technoculture, humanist

\section{Introduction}

Every human being wants to live prosperously. Food, clothing, and housing are very important things in life. Article 28 $\mathrm{H}$ of the 1945 Constitution of the Republic of Indonesia emphasizes that people have the right to live wealthy physically and spiritually, to find a good and healthy environment, and to get good health services. It means that the State must be present so that people can meet their primary needs, namely food, clothing, and housing (Sukmana, 2016). The fulfillment of these three basic needs is an important requirement in an independent and sovereign nation. The reality is that nowadays in society there are still a lot of people living in poverty. UNICEF defines poverty as a lack of material things minimal needs humans including health, education and other services which can prevent people from poverty (Irsad,
2014). This was caused by several reasons, for example, the difficulties of finding jobs, difficulties to find capital and etc. Various efforts have carried out by the government such as monetary, fiscal and etc. However, it has not maximally reduced the poverty number. Based on the report from Indonesia's Central Statistics Agency (BPS) in March 2018, Indonesians who are categorized as poor are around 25.95 million people or $9.82 \%$ of the total Indonesian population. (https://www. bps.go.id/pressrelease/2018/07/16/1483/ persentase-penduduk-miskin-maret-2018turun-menjadi-9-82-persen.htm//22-72018/21.09). In general, the condition of Indonesian's economy poverty has increased especially since the 1997 economic crisis until now. Economic activity tends to weaken, marked by increasing unemployment as well as a decrease in people's welfare (M.

Received: 2019-07-18, Revised: 2019-09-24, Accepted: 2019-12-23 
Dikron, 2005). World Bank (World Bank) note that half of the population in Indonesia lives in poverty or vulnerable to poverty, with a condition of almost $42 \%$ of homes the staircase lives between the lines poverty of US \$1- and the US $\$ 2$ per day (Firmasyah, 2013). Those poor people must be helped so that the burden of their lives can be reduced. Not only in Indonesia but also in the world, not only today but also in ancient times, people who were less fortunate in terms of welfare were always there. Therefore, a solution is needed to overcome this problem. Religion has provided the solution, namely with the concept of donating a portion of the wealth of rich people. In Islam, this is referred to as "zakat". People who have fulfilled the minimum requirements for zakat are obliged to give their possessions to those who have the right to get it (mustahiq). Zakat is one of the pillars in the pillars of Islam as a form of social action that must be done by every Muslim. Zakat cleanses the soul from stinginess, greed and selfishness; purifies property from the rights of others; and has a positive impact on the economy community by reducing poverty increasing economic growth and increasing purchasing power parity (Clarashinta, 2017). This is ordered by God, so that it will not only be a perpetual distribution among the rich (Qur'an [7]:59) but can also be perpetual among poor people or "Faqir". Zakat will make the economy move Quickly, a brotherhood builds between economic actors and inequality the economy will narrow (Novianto, 2014)

Zakat in Islam is categorized as worship of hablu minannas (relationship among human/ horizontal worship). if Prayers is the most important physical worship, while zakat is the most worship of maliyah (property). Harmony between the two is absolutely realized to build a solid, based social order on the balance of religious and economic values (Anis, 2017). Islam suggests the privileges of vertical worship (hablu minallah) and horizontal worship, therefore many verses in the Qur'an that juxtapose vertical and horizontal commands. An example is "And establish prayer and give zakah" (Qur'an $2: 43)$. Regarding this verse, al-Hasan al-Basri said: "It will not be useful for practice without establishing prayer and paying zakah". (Ibn Katsir, 2005). Thus, mustahiq is expected will change its status to muzakki. So that the poverty rate in the community can be reduced by a change in the status of Mustahiq to become Muzakki. The role of zakat on macro if we look at the history of the caliph Umar's administration Ibn Khattab, that zakat is the source of income for the Islamic State besides Tax and so on. 3 So that zakat has a very central role in it Islamic economics. not only individuals can feel the positive impact zakat, but a State can also feel the impact of zakat for the country's economy, namely as another source of state income (Ridho, 2014). The great potential of ZIS per year is expected to be able to overcome the problem of poverty in Indonesia, which reached 29.89 million people $(12.36 \%)$ of Indonesia's population in 2011.11 To realize this, collaboration from various parties, the particularly active role of zakat management institutions. Since the birth of Law No. 38 of 1999 concerning Management of Zakat, zakat management institutions established either by the government or by non-governmental organizations at the central or regional levels began to emerge and obtain legality from the state. According to Imam Suprayogo, the Islamic community in Indonesia no longer has difficulty in distributing zakat, infaq, or sadaqah. Moreover, some zakat management institutions have volunteers who are willing to calculate how much zakat must be issued, take it and distribute it to those who are entitled to receive it (Ramadhita, 2012)

The concept of charity not only in Islam but also in Christianity, Christians are commanded to glorify God. Among the forms of glorification to God is by issuing a portion of their possessions (Proverbs 3: 9 and Mal 3:10). In the beginning, the concept of tithing was taught to the people of Israel. The offering is handed over to the Imam. The Imams do not get the inheritance. Their duty is fully serving God. Therefore, their lives are supported by gifts from Jews in the form of offerings. Also, tithe offerings are intended for the poor and orphans.

When you have finished setting aside a tenth of all your produce in the third year, the year of the tithe, you shall give it to the Levite, the foreigner, the fatherless and the widow, so that they may eat in your towns and be satisfied. (Deutronomy 26:12)

God's promise to the people of Israel who faithfully offer tithes is in the form of abundant blessings or fortune. It is said in Malachi 3:10 that God will not throw open the floodgates of heaven and pour out so much blessing that there will not be room enough to store it.

In Hinduism, It is also taught the 
concept of a charity called punia. Every person ordered to work hard so far from destitute and deprived conditions, after getting wealth from his/her hard work, then he/she is ordered to donate a portion of it to the community so that it can be useful (Atharva Veda VI.81.1). Likewise with other religions where each adherent is ordered to donate his/her wealth to the people who have the right to get it, and it is done as a form of worship to the Creator.

Conventional Technique of charity fundraising, both zakat, tithe, and punia are still practiced today. The provision of several branch offices of Amil Zakat or several counters where donors can visit to donate part of their wealth or the donation is picked up by officials from Amil Zakat institutions from the donors is one of the conventional methods that are still used today. Likewise, with tithing, the donors provide empty boxes as a place of offering and are labeled: "Persembahan Persepuluhan" which is then handed over to the church, and by the church, it is distributed to those who need it.

Along with the development of age, the use of technology becomes a necessity to facilitate easy access to human necessities. The development of internet media (online) that is so fast can be seen in the level of use of this media among American society for example, in 1998 there were only 1 in 5 people reading the internet, but two years later it increased to 1 in 3 people already a user. This progress also occurs in the legislative field, where the US Congress who usually only receive 500 emails per week, now increasing to 2000 email, or up by around 400 percent. The same situation also occurred in Buenos Aires, Brazil in 2002, where government institutions received on average received more than 400 e-mail messages per day, and some of their staff spent about 1 hour per day receiving these messages. The development of internet media has a very significant influence on each country. Indonesia is one of the countries that experienced this impact. Data from the Indonesian Internet Service Providers Association (APJII), states that in Indonesia there are around 25 million internet users. Every year internet users continue to increase by around 25\% (Daryanto, 2018).

Internet media (online) not only used as a means to facilitate social communication but also nowadays the activities of selling and purchasing are using online. Just only with trust between the sellers and buyers, they can make transactions without having to meet each other. Not only in profit activities but also the role of internet technology is also very large in social-worship activities. Zakat for example (Afriyenis, 2018). The year 2004 marked the beginning of the construction of information technology systems for improving the quality of service of zakat institutions (Syahriza, 2019). Almost all branch offices have been connected online (Rohim, 2019). And in 2005 the institution's information system began to enter the network online, including online transactions, absence lines, and financial software (Wahyuni, 2017). It is not uncommon for us to listen to "advertisements" of online zakat services. A Muslim who has entered the compulsory category to issue zakat, can pay his/her zakat just by using a smartphone which has been installed an online zakat application, thus funds can be transferred without visiting the zakat management office or even meet the mustahiq.

Likewise tithe in Christianity, punia in Hinduism and also the concept of charity in other religions. Besides the positive side, namely easiness, the negative side of technology usage in charity is very likely occurred. Some of these weaknesses include the loss of personal relationships between donors and recipients, the loss of charity distribution opportunities to those who are closer to donors which actually are the top priority in zakat, and the absence of assessment about the source of donations that are given. Therefore, the aim of this research is to analyze the positive and negative sides of the role of internet technology, especially in the activities of charity fundraising from people who have an adequate amount of wealth in the terms of economics. The output is the mapping of online charity fundraising problems and the improvement of online charity fundraising designs that are more humane.

\section{Research Methodology}

Basically, the research formulated in the topic "The Development Of Information Technology Applications Of Religious Charity Through Humanities Technology Approach "is a step towards of improvement in the role of information technology based on the observation of the phenomenon of online charity fundraising that deals with humanity and the culture of a more humane society. 


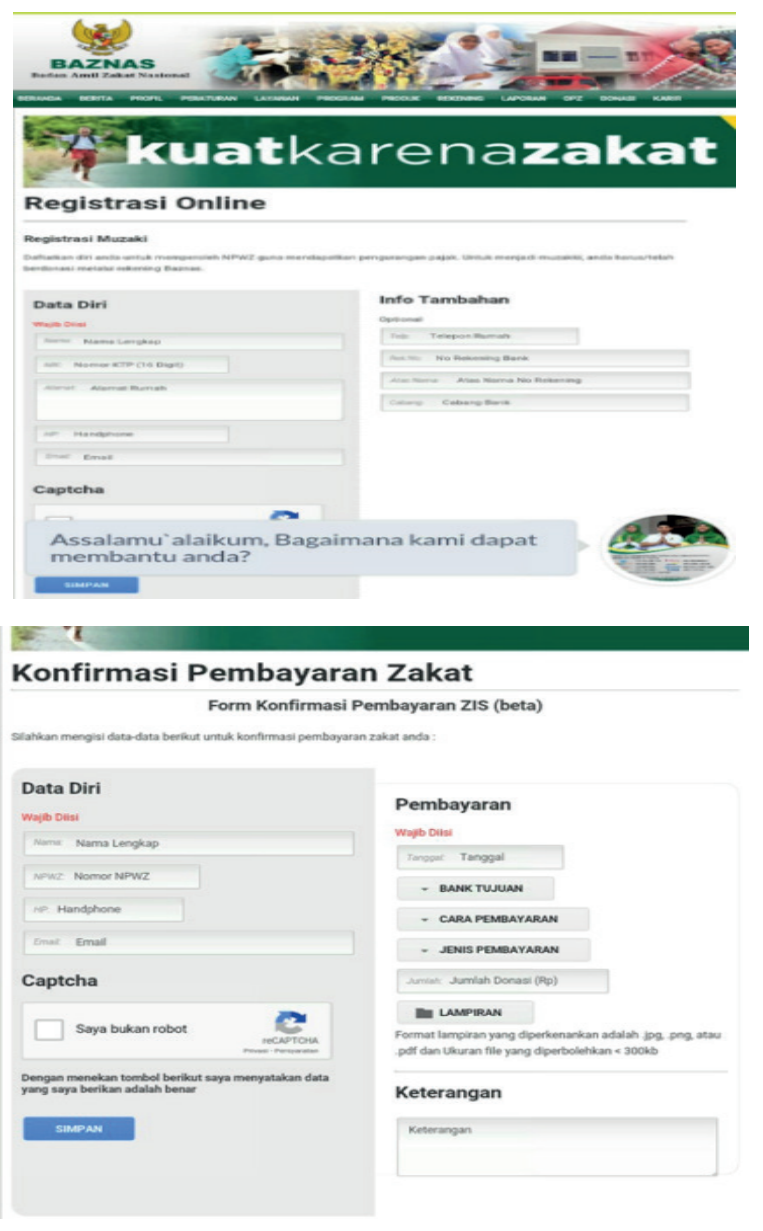

Figure 3: Baznas(fundraising) Service

In general, in conducting fundraising, BAZNAS uses two methods, namely:

\section{Conventional}

That is by providing several branch offices in several regions and the muzakki can visit them to pay zakat or the donation is picked up by Baznas officers

\section{Spreading Bank Account Number}

BAZNAS distributes several bank account numbers to the public as a means to transfer zakat funds. However, before transferring, BAZNAS also provides an online registration form for designate muzakki, so that the muzakki can be registered. BAZNAS also provides an online confirmation form that can be used by muzakki after transferring their funds (zakat).

\section{Analysis}

Based on the description of some charitable institutions' activities above, this study found some benefits of internet technology usage in conducting its management, both related to fundraising activities and its distribution. These benefits include:

Practicality. Through an online approach, a donor does not need to visit the charity office to donate part of his/her wealth.

Time efficiency. The online scheme does not take time for donors because they do not need to visit charity institutions, so that time can be used for other activities.

Convenience. The online scheme makes it easy for charity institutions to socialize various activities and reports, and provide convenience for donors to distribute part of their wealth effectively.

Knowledge development. The online scheme provides unlimited facilities for all parties to broadcast and absorb various information and knowledge, especially relate and to charity.

Effective educational media. The online scheme that presents various charitable programs and reports on charity distribution activities is an important instrument in educating the public to grow sympathy and empathy for the fate of fellow beings.

In addition to the great advantages of implementing internet technology in fundraising, this research found several disadvantages in online fundraising institutions. These disadvantages are:

Loss of personal relationships between donors and beneficiaries. In Islam, there are three kinds of charity: The first compulsory charity such as Zakat, the second charity that is suggested such as shadaqah, the third charity that is voluntarily such as infaq. Philosophically, the essence of zakat not only is the distribution of wealth from rich to poor (Abu Dawud, 2008), but also to build personal relationships frame in communities, so that the rich can feel the bitterness of the poor, and the poor can thank the rich, by this scheme, there is no hate and envy. The brotherhood among communities is getting stronger because each of the people cares for each other and knows the fate of its brother, zakat is an embodiment of social solidarity (Yunus, 2016). Rasulullah said: "The parable of the believers in their affection, mercy, and compassion for each other is that of a body. When any limb aches, the whole body reacts with sleeplessness and fever." (Muslim, 2004). In the management 
of fundraising carried out by online charity institutions above, no instruments were found that bridged the possibility to establish direct or indirect communication between the charity donors and recipients. Thus eliminating part of the main mission of compulsory charity (zakat) as contained in the philosophical values expressed above.

The loss of charity distribution opportunities to beneficiaries who are closer to donors.

In distributing compulsory charity in the form of zakat, there is a recipient scale of priority. Priority Zakat recipients according to Quran are the people who are closest to Muzakki. more than that zakat can be distributed if there is the certainty that the recipient is poor, and better if it is known by muzakki (Yunus, 2016). They ask you, [O Muhammad], what they should spend. Say, "Whatever you spend of good is [to be] for parents and relatives and orphans and the needy and the traveler. And whatever you do of good - indeed, Allah is Knowing of it." (Al-Baqarah [2]: 215) The relatives in the verse are interpreted as siblings who have nasab (Ibn Katsir, 2005), but if it is further developed it is not only defined as relatives from the nasab side, but relatives in terms of the closeness of personal relationships (Istikhomah, 2019). In fundraising management carried out by online charity institutions above, no instruments were found which accommodate the priority of beneficiaries. The distribution of charity is entirely left to the charity (amil zakat agency) without muzakki knows about it, whereas the obligation to implement accountability by LAZ has been claimed under Law No. 38 of 1999 on zakat management (Nikmatuniayah, 2017).

\section{There is no assessment regarding the source of donations from donors}

Things that cannot be ignored regarding charity both compulsory and sunnah (which is recommended) to voluntary donations (infaq) are related to the sources of wealth owned by donors and then used as a donation (Suratmaputra, 2017). Prophet Muhammad, for example, said: "O people, indeed Allah is good and does not accept except the good" (Bukhari, 2000). One of the obligatory requirements of zakat that has been agreed upon by the ulama is full ownership of the property (Jamaa, 2015).
Illegal money owned by a person is essentially not his property but belongs to someone else or the institution where he took the money. because full ownership of property which is one of the mandatory conditions of zakat is not fulfilled on that person. Therefore there is no obligation of zakat for him. Zakat assessment is important to be done to ensure that zakat is valid and accepted. In fundraising management carried out by online charity institutions above, no instruments found can be used to conduct assessments related to cleanliness and halal relate to sources of wealth used by the donors.

\section{Solution}

Based on the analysis of the management of online charity institutions as described above, we recommend the need to include the following three things as a concrete step to improve the design of online charity fundraising:

To overcome the loss of personal relationships between donors and recipients, it is necessary to make a "distribution of donations" form that specifically confirms the willingness of donors to be identified by beneficiaries.

PERSONAL RELATIONSHIP FORM

Are you willing to show your profile to the recipient?

a. Yes

b. No

To maintain the priority of charity recipients (zakat), it is necessary to make a "charity purpose" form that specifically confirms the possibility of certain people who close to the donors and expected by him/her to be the recipient of his/her donation.

\section{PRIORITY DISTRIBUTION FORM}

Is there any priority person to be helped support by you?

a. Yes

b. No

If "yes", please mention people who need to be supported:

For the assessment of charity sources, it is necessary to make a statement form about wealth that is donated as originating from good and lawful ways. 
CHARITY SOURCE STATEMENT FORM

"For God's sake I swear that the wealth that I am donated is accounted for "

Signature

\section{Conclusions}

Descriptions and analysis of the work management of online charity institutions above resulted in conclusions that the existing online charity fundraising services have fulfilled the feasibility of the service system both in the fundraising aspect of charity and its distribution. However, online charity services viewed from the perspective of personal relations have resulted in relatively crucial side effects, which must be addressed immediately, especially in relation to the loss of personal relationships between donors and beneficiaries, and the loss of charity philosophical values, especially from religion sides. This research presents recommendations of fundraising design improvement for online charity fundraising to overcome the significant weaknesses above, namely by improving the online fundraising patterns through the creation of three designs: Personal Relations Form, to guarantee the emotional connection between muzakki and mustahiq. Priority Distribution Form, to guarantee the distribution of funds according to the priority scale determined by religion. and Charity Source Statement Form, to guarantee the halal of muzakki funding sources.

\section{References}

Abu Dawud, (2008). Sunan Abu Dawud, Dar ar-Rayyan, Beirut.

Afriyenis, W. (2018). Implementasi Teknologi Informasi dan Komunikasi dalam Zakat Untuk Meningkatkan Kesejahteraan Masyarakat Miskin, JEBI (Jurnal Ekonomi dan Bisnis Islam) - Vol. 3, No. 2.

Andriyanto, I. (2014). Pemberdayaan Zakat dalam Peningkatan Kesejahteraan Umat, ZISWAF, Vol. 1, No. 2.

BPS. (2018). Presentase Penduduk Miskin Maret 2018 Turun Menjadi 9,82 Persen. https://www.bps.go.id/ pressrelease/2018/07/16/1483/ persentase-penduduk-miskin-maret2018-turun-menjadi-9-82-persen. $h t m l / 22-7-2018 / 21.09$

Bukhari. (2000). Al-Jami' ash-Shahih, Maktabah Salafiyyah, Kairo.

Canggih, C. (2017). Inklusi Pembayaran Zakat di Indonesia. Jurnal Ekonomi dan Bisnis Islam, Vol. 3, No. 1.

Daryanto, S. (2018). Dampak Perkembangan Teknologi Informasi dan Komunikasi Terhadap Budaya Simbolika, Vol. 4 No.1.

Dzikron, M. (2005). Efektifitas Organisasi Zakat dalam Pemberdayaan Ekonomi Masyarakat. MIMBAR, Vol. XXI, No. 3 Juli - September 2005 : 297 - 310.

Firmasyah. (2013). Zakat Sebagai Instrumen Pengentasan Kemiskinan dan Kesenjangan Kesejahteraan. Jurnal Ekonomi dan Pembangunan Vol 21, No. 2.

Ibnu Katsir. (2005). Tafsir al-Quran al-Adzim, Dar al-Hadits Kairo.

Istikhomah, D. (2019). Pengaruh Literasi Terhadap Kepercayaan Muzaki Pada Lembaga Pengelola Zakat dengan Akuntabilitas dan Transparansi Sebagai Variabel Interventing. Economic Education Analysis Journal, Vol. 8, No. 1.

Jamaa, L. (2015). Pemanfaatan Uang Korupsi Untuk Kepentingan Umum: Analisis Fiqh. Jurnal Al-Mizan, Vol. 11 No. 1

Kuncoro, A.T. (2017). Zakat: Katup Pengaman Keseimbangan Ekonomi Umat. Ulul Albab, UNISULA Vol. 1, No. 1.

Muslim. (2004). Shahih Muslim, Dar at-Taqwa, Kairo.

Nikmatuniayah. (2017). Effects of Accounting Information Quality, Accountability, and Transparency on Zakat Acceptance. MIMBAR, Vol. 33, No. 1st (June, 2017) pp 62-73

Novianto, H.R. (2014). Mengapa Masyarakat Memilih Menunaikan Zakat di Mesjid dibandingkan dengan Lembaga Zakat?. ESTT Vol. 1 No. 3.

Ramadhita. (2012). Optimalisasi Peran Lembaga Amil Zakat Dalam Kehidupan Sosial. Jurnal Hukum dan Syariah, Vol. 3, No. 1.

Ridlo, A. (2014). Zakat Dalam Perspektif Ekonomi Islam. Jurnal al-'Adl, Vol. 7 No. 1.

Rohim, A.N. (2019). Optimalisasi Penghimpunan Zakat Melalui Digital Fundraising. Al-Balagh: Jurnal Dakwah dan Komunikasi, Vol. 4, No. 1.

Sukmana, O. (2016). Konsep dan Desain Negara Kesejahteraan (Welfare State), Jurnal Sospol, Vol 2 No.1.

Suratmaputra, A.M. (2017). Problematika Uang Haram dalam Kajian Fiqh. Misykat, 
Vol. 2, No. 1.

Syahriza, M. (2019). Analisis Efektivitas Distribusi Zakat Produktif Dalam Meningkatkan Kesejahteraan Mustahik (Studi Kantor Cabang Rumah Zakat Sumatera Utara. AT-TAWASSUTH. Vol. 4 No. 1.

Wahyuni, S. (2017). Peran LAZ Sebagai Pengelola Zakat dalam Pendayagunaan
Zakat Produktif. AT-TAFAHUM: Journal of Islamic Law, Vol. 1 No. 2..

Yunus, M. (2016). Analisis Pengaruh Kepercayaan, Religiusitas dan Kontribusi Terhadap Minat Pedagang Mengeluarkan Zakat di Baitul Mal (Studi Kasus Pada Pedagang Pasar Los Lhokseunawe) AtTawassuth UIN-SU, Vol. 1, No 1. 